\title{
Pengaruh Blended Learning terhadap Kemampuan Berpikir Kritis Siswa SMA pada Materi Suhu dan Kalor
}

\author{
Anggian Anggraeni ${ }^{1}$, Edi Supriana ${ }^{1}$, Arif Hidayat ${ }^{1}$ \\ ${ }^{1}$ Pendidikan Fisika-Universitas Negeri Malang
}

\begin{tabular}{l} 
INFO ARTIKEL \\
\hline Riwayat Artikel: \\
Diterima: $24-04-2019$ \\
Disetujui: 23-06-2019 \\
\hline
\end{tabular}

\section{Kata kunci:}

blended learning;

critical thinking skills; temperature and heat;

blended learning;

kemampuan bepikir kritis;

suhu dan kalor

\author{
Alamat Korespondensi: \\ Edi Supriana \\ Pendidikan Fisika \\ Universitas Negeri Malang \\ Jalan Semarang 5 Malang \\ E-mail: edi.supriana.fmipa@um.ac.id
}

\begin{abstract}
ABSTRAK
Abstract: The purpose of this research is to know the effect of blended learning on students' critical thinking skills in the heat and temperature material. The sample of this study was students of SMA Negeri 5 Malang consisting of 2 class, that is XI G-3 class as a control and XI H-3 class as an experimental class with 34 people in each class. This research design used a posttest only control group that is analyzed quantitatively. The results of this research show that there is an effect significantly of blended learning on students' critical thinking skills in temperature and heat material.

Abstrak: Tujuan penelitian ini adalah untuk mengetahui pengaruh blended learning pada keterampilan berpikir kritis siswa dalam materi suhu dan kalor. Sampel penelitian ini adalah siswa SMA Negeri 5 Malang yang terdiri dari dua kelas, yaitu kelas XI G-3 sebagai kelas kontrol dan kelas XI H-3 sebagai kelas eksperimen dengan 34 siswa di setiap kelas. Desain penelitian adalah posttest only control group design yang dianalisis secara kuantitatif. Hasil penelitian menunjukkan bahwa ada pengaruh yang signifikan dari blended learning pada keterampilan berpikir kritis siswa dalam materi suhu dan kalor.
\end{abstract}

Pada era globalisasi saat ini, perkembangan teknologi terjadi dengan sangat pesat. Perkembangan teknologi dalam dunia pendidikan dapat membantu meminimalisasi penggunaan kertas dalam pembelajaran (Rosenberg, 2002). Berkembangnya teknologi tidak hanya terjadi pada alat-alat teknologi, tetapi terjadi pada penggunaan jaringan online pada pembelajaran. Pembelajaran yang menggunakan teknologi daring dapat membantu siswa dalam menerima informasi atau materi pendalaman dari guru (Warschauer, 2004; Yapici \& Akbayin, 2012). Tujuan dari penggunaan jaringan online pada pembelajaran, yaitu guru dapat memberikan materi pendalaman sehingga siswa mendapatkan informasi tambahan pada suatu materi yang sedang dipelajari di kelas (Jou, et al., 2014; Kayler \& Weller, 2007), membantu memperbaiki kesalahan konsep siswa (Demirci, 2007). Hal tersebutlah yang menuntut guru untuk dapat menggunakan strategi yang sesuai dalam pembelajaran supaya tujuan pembelajaran fisika dapat tercapai.

Pembelajaran yang dilakukan guru pada saat ini masih menggunakan pembelajaran tatap muka. Pembelajaran tatap muka yang digabungkan dengan pembelajaran daring dinamakan sebagai blended learning (Akyuz \& Samsa, 2009; Anggraini et al., 2016; Kiviniemi, 2014; Korkmaz \& Karakus, 2009; Wong et al., 2014; Yapici \& Akbayin, 2012). Blended learning merupakan salah satu alternatif strategi pembelajaran yang dapat digunakan oleh guru pada era globalisasi saat ini (Aslam, 2015). Hal tersebut dikarenakan blended learning dapat dilakukan oleh guru dimana saja dan kapan saja (Alonso, et al., 2005). Sehingga penggunaan blended learning dapat menambah pengetahuan siswa (Chew \& Wee, 2015).

Teknik blended learning yang diterapkan oleh guru memiliki beberapa keuntungan. Keuntungan seperti pembelajaran daring dapat membantu siswa untuk dapat belajar secara mandiri tanpa bimbingan guru secara langsung, membantu pembelajaran konvensional yang sering dilakukan guru sehingga membantu siswa memperoleh informasi tanpa harus bertatap muka dengan guru (Anggraini, et al., 2016), meningkatkan rasa ingin tahu siswa terhadap suatu informasi, pembelajaran yang fleksibel, dan dapat mengurangi biaya yang digunakan dalam proses pembelajaran pada umumnya (Collins, et al., 2003; Garnham \& Kaleta, 2010). Selain itu, siswa dapat belajar sesuai dengan kecepatan belajarnya masing-masing tanpa dipengaruhi oleh temannya (Yapici and Akbayin, 2012). Penelitian sebelumnya menghasilkan bahwa teknik blended learning dapat memengaruhi hasil belajar siswa (Wong et al., 2014), memberikan hasil positif pada pemecahan masalah dan pemahaman konsep siswa pada suatu materi (Kurniawan, 2014; Sudiarta \& Sadra, 2016), meningkatkan hasil belajar siswa (Ceylan \& Kesici, 2017). Blended learning juga terbukti dapat meningkatkan kemandirian mahasiswa dalam belajar dan kemampuan berpikir kritis mahasiswa (Sari, 2013) dan dapat melatih kemampuan berpikir kritis mahasiswa (Fitriani \& Ikhsan, 2017). 
Kemampuan menerima materi yang dimiliki siswa berbeda satu sama lainnya karena kemampuan tersebut ditentukan oleh kemampuan berpikir pada masing-masing siswa (Budiarti, et al., 2017). Berpikir kritis merupakan salah suatu hal yang dianggap sebagai kemampuan yang sangat penting dalam proses pembelajarannya (Huber \& Kuncel, 2015). Saat ini, siswa kesulitan dalam mengembangkan kemampuan berpikir kritisnya karena pembelajaran yang diberikan oleh guru masih dilakukan dengan metode konvensional atau ceramah (Fatmawati, et al., 2014). Selain itu, pembelajaran yang dilakukan lebih ditekankan pada hafalan dan hanya membaca materi (Hong, et al., 2012). Kemampuan berpikir kritis seseorang dapat dilihat dari caranya memberikan pendapat dengan percaya diri dan bagaimana caranya bertindak dengan memberikan alasan (Mabruroh \& Suhandi, 2017). Pada dunia pembelajaran, kemampuan berpikir kritis siswa perlu dikembangkan agar siswa menggunakan pemikirannya secara kritis untuk memecahkan suatu permasalahan yang diberikan (Mabruroh \& Suhandi, 2017).

Kegiatan belajar dan pembelajaran akan berjalan lancar dan sesuai dengan tujuan pembelajaran jika guru dapat menentukan strategi belajar yang cocok sehingga pembelajaran dapat berjalan dengan maksimal (Dwi et al., 2013; Kartal et al., 2011). Selain itu, guru dapat menggabungkannya fenomena yang terjadi dalam kehidupan sehari-hari dengan materi pembelajaran yang akan dipelajari (Kartal, et al., 2011). Permasalahannya apakah teknik blended learning dapat memengaruhi kemampuan berpikir kritis siswa. Oleh karena itu, tujuan dari pelaksanaan penelitian ini adalah untuk dapat mengetahui pengaruh blended learning terhadap kemampuan berpikir kritis siswa pada materi suhu dan kalor.

\section{METODE}

Penelitian yang dilakukan menggunakan rancangan penelitian experiment quasi dengan desain posttest only control group design. Rancangan penelitian yang dilakukannya dapat dilihat pada tabel 1.

Tabel 1. Rancangan Pelaksanaan Penelitian

\begin{tabular}{lll}
\hline Kelompok Kontrol & Tidak ada perlakuan & Posttest \\
\hline Kelompok Eksperimen & Perlakuan eksperimental & Posttest \\
\hline
\end{tabular}

Lokasi penelitian dilakukan di SMA Negeri 5 Malang yang terletak pada Jalan Tanimbar no 24, Klojen, Kota Malang, Jawa Timur. Seluruh siswa kelas XI yang terbagi atas 11 kelas menjadi populasi dalam penelitian ini. Sampel penelitian ini diambil berdasarkan teknik purposive sampling, dimana kelas eksperimen dan kelas kontrol dipilih oleh guru secara langsung dengan pertimbangan tertentu. Sehingga didapatkan sampel penelitian kelas XI G-3 (kelas kontrol) dan kelas XI H-3 (kelas eksperimen). Jumlah siswa pada kelas XI G-3 dan kelas XI H-3 yang mengikuti pembelajaran dengan teknik blended learning sebanyak 34 siswa untuk masing-masing kelas.

Pelaksanaan penelitian menggunakan instrumen tes kemampuan berpikir kritis siswa berubah tes uraian pada materi suhu dan kalor. Instrumen penelitian tersebut telah divalidasi oleh dua orang dosen dan diuji coba kepada 84 siswa untuk melihat kelayakan instrumen penelitian yang akan digunakan. Hasil dari uji coba yang telah dilakukan tersebut menghasilkan bahwa nilai reliabilitas instrumen kemampuan berpikir kritis siswa adalah 0,828 . Hal tersebut menunjukkan bahwa instrumen yang akan digunakan dalam penelitian telah layak. Instrumen penelitian yang digunakan lima butir soal kemampuan berpikir kritis. Setiap butir soal telah mewakili lima indikator sesuai dengan indikator kemampuan berpikir kritis pada materi suhu dan kalor.

Data penelitian yang telah diperoleh kemudian dianalisis untuk dapat mengetahui pengaruh penggunaan teknik blended learning terhadap kemampuan berpikir kritis siswa pada materi suhu dan kalor. Analisis statistik data penelitian dengan menggunakan uji beda. Akan tetapi, sebelum dilakukannya analisis uji beda dilakukan uji prasyarat.

\section{HASIL}

Pembelajaran yang dilakukan pada penelitian ini yaitu dengan menggunakan teknik blended learning. Blended learning merupakan pembelajaran yang menggabungkan pembelajaran tatap muka dan pembelajaran daring. Pembelajaran daring pada penelitian ini menggunakan Learning Management System berbentuk Schoology. Pembelajaran daring yang dilaksanakan setelah pembelajaran tatap muka. Guru memberikan materi, video, dan tugas dengan jumlah empat kali pertemuan. Setiap pertemuan pada pembelajaran daring, mewakili setiap sub materi yang diajarkan pada pembelajaran tatap muka.

Siswa yang telah mengikuti pembelajaran dengan menggunakan teknik blended learning dan metode konvensional pada kelas eksperimen dan kelas kontrol secara berturut-turut kemudian mengikuti posttest. Posttest yang dilakukan oleh siswa untuk mengukur kemampuan berpikir kritis siswa pada materi suhu dan kalor. Siswa menjawab setiap pertanyaan yang diberikan oleh guru berdasarkan indikator kemampuan berpikir kritis. Hasil deskriptif data pada hasil posttest kemampuan berpikir kritis siswa dapat dilihat pada tabel 1. Berdasarkan pada tabel 1, dapat diketahui bahwa siswa kelas eksperimen memiliki nilai rata-rata posttest yang lebih tinggi daripada siswa kelas kontrol. Perbedaan nilai posttest pada kelas eksperimen dan kelas kontrol sebesar 17,00. 
Tabel 1. Hasil Analisis Data Deskriptif Posttest Kemampuan Berpikir Kritis

\begin{tabular}{ccc}
\hline Parameter & Kelas Eksperimen & Kelas Kontrol \\
\hline $\mathrm{N}$ & 34 & 34 \\
\hline $\mathrm{X}$ & 69,76 & 52,76 \\
\hline $\mathrm{Xmin}$ & 36 & 20 \\
\hline $\mathrm{Xmax}$ & 88 & 84 \\
\hline $\mathrm{Sd}$ & 11,481 & 14,884 \\
\hline
\end{tabular}

\section{PEMBAHASAN}

Blended learning adalah salah satu teknik pembelajaran yang memadukan pembelajaran tatap muka di dalam kelas dengan pembelajaran daring di luar kelas. Pembelajaran tatap muka dilakukan dengan cara penjelasan materi oleh guru. Guru menjelaskan materi dengan menggunakan metode ceramah, diskusi, tanya jawab, dan pembelajaran penugasan. Selain itu, guru mengajak siswa untuk melakukan percobaan agar siswa tetap berperan aktif dalam pembelajaran yang dilakukan. Pada tahap pendahuluan, guru memeriksa kehadiran siswa, memberikan motivasi belajar dan apersepsi yang sesuai dengan materi suhu dan kalor. Pada tahap inti pembelajaran, guru menjelaskan materi dan mengajak siswa untuk melakukan percobaan yang berkaitan dengan materi suhu dan kalor. Siswa melakukan percobaan secara berkelompok, melakukan diskusi, dan mempresentasikan hasil percobaan tersebut di depan kelas. Siswa kemudian memperhatikan penjelasan guru berkaitan dengan penguatan dan pembenaran materi yang masih tidak dipahami oleh siswa. Siswa juga mengerjakan contoh soal yang telah diberikan oleh guru sebelumnya. Terakhir, pada tahap penutup, siswa diberikannya tugas rumah untuk penguatan pemahaman konsep siswa terhadap materi yang telah dipahami tersebut. Pembelajaran tatap muka dilakukan selama tiga minggu.

Pembelajaran daring yang digunakan dalam penelitian ini menggunakan Learning Management System berupa Schoology. Pada pembelajaran daring tersebut, siswa diminta memasuki schoology yang telah diperseiapkan guru dengan kode akses 44BKS-FJQP5. Pada setiap akhir pembelajaran tatap muka, siswa akan menggunakan fasilitas daring sebagai penguatan materi dan penugasan. Materi yang disampaikan pada pembelajaran daring lebih bervariatif, seperti berbentuk video, gambar, dan teks. Setelah siswa mengerjakan tugas yang diberikan, siswa tersebut akan mengunggah jawabannya dan kemudian diberi skor oleh guru.

Pembelajaran daring yang dilakukan oleh siswa dilakukan setelah proses pembelajaran tatap muka selesai dilakukan, tetapi tidak membatasi pada hari lain untuk siswa untuk melakukan pembelajaran kapan saja dan dimana saja. Tampilan pembelajaran daring yang diterima oleh siswa terlihat pada gambar 1 dan 2.

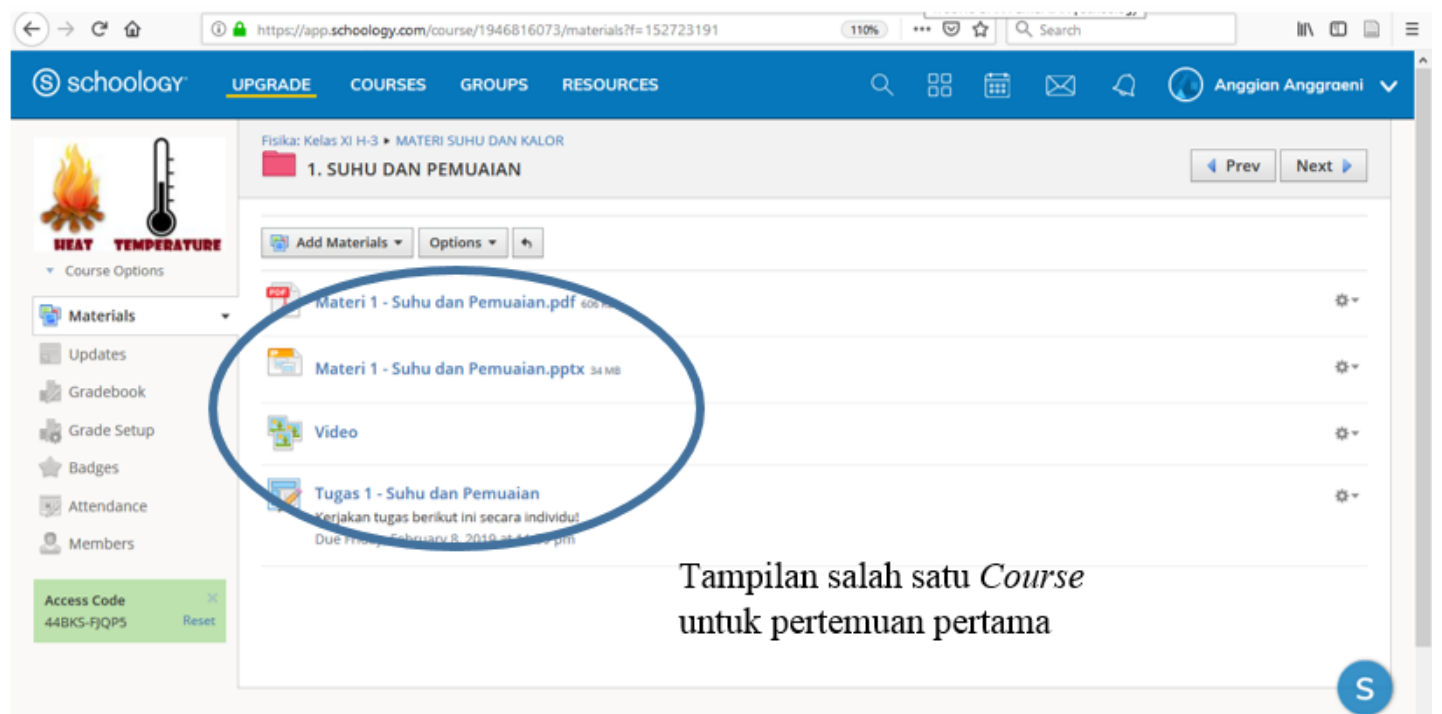

Gambar 1. Salah Satu Tampilan Course Pembelajaran Daring Materi Suhu dan Kalor Siswa 


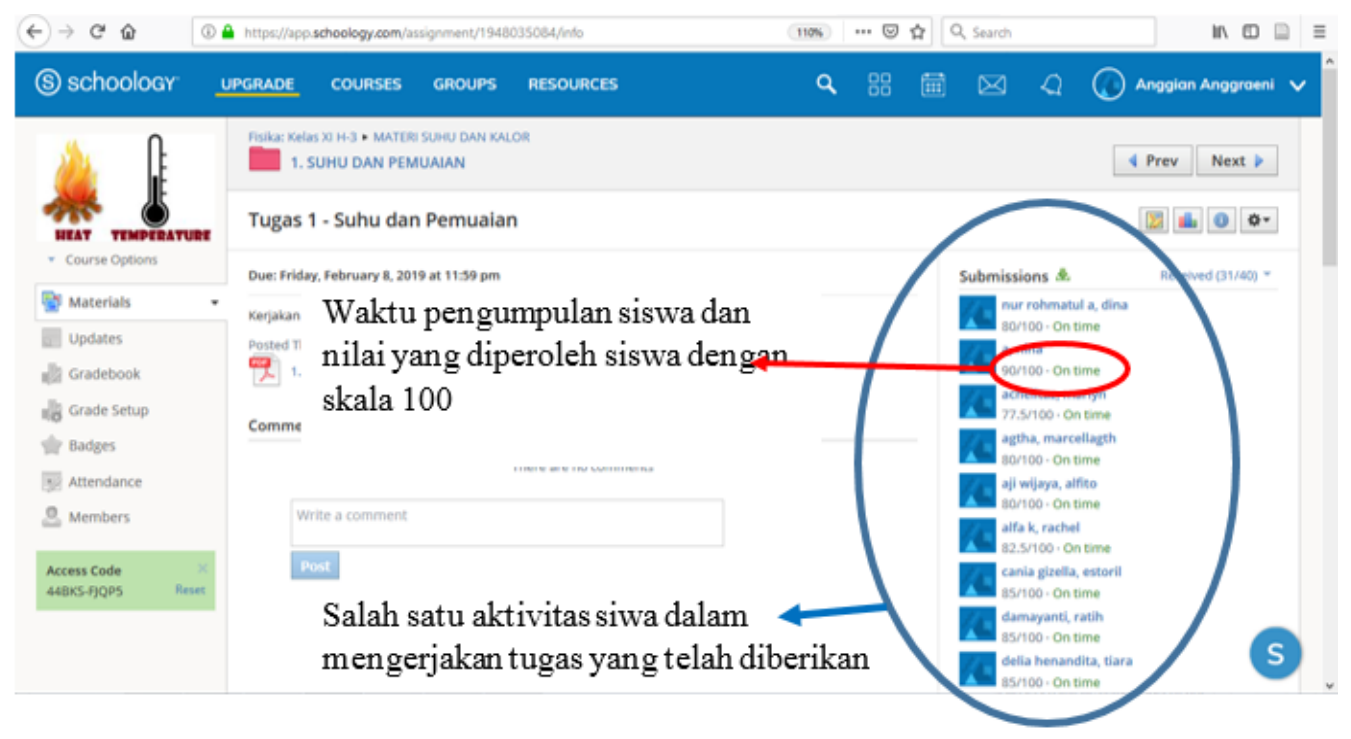

Gambar 2. Salah Satu Tampilan Aktivitas Siswa

Gambar 1 menunjukkan tampilan satu pertemuan daring yang diperoleh siswa dalam pembelajaran daring. Gambar 2 menunjukkan bahwa kegiatan yang dilakukan siswa dalam pembelajaran. Siswa mendapatkan tugas sesuai dengan materi yang telah dipelajari sebelumnya. Kemudian siswa mengunggah jawaban tugas tersebut sebelum waktu pemberian tugas habis.

Pelaksanaan blended learning pada penelitian yang dilakukan memiliki kekurangan dan kelebihan. Kekurangan pada penelitian yang dilakukan antara lain jaringan internet untuk mengakses pembelajaran daring masih belum maksimal dan masih terdapat beberapa siswa yang tidak mengikuti pembelajaran daring ada sub materi tertentu yang ditunjukkan dengan pengerjaan tugas siswa yang tidak dilakukan oleh beberapa siswa. Guru telah memberi jeda hari pemberian tugas dan pengumpulan tugas dengan tujuan siswa dapat mengerjakan tugas yang diberikan secara maksimal. Akan tetapi, beberapa siswa tidak mengumpulkan hasil pengerjaannya.

Keuntungan pelaksanaan blended learning yang dilakukan pada penelitian ini antara lain teknik ini memungkikna siswa unuk dapat belajar dimana saja dan kapan saja. Siswa dapat mendalami materi yang sedang dipelajari secara mandiri. Selain itu juga, blended learning ini juga dapat meningkatkan kemampuan berpikir kritis siswa. Hal ini terlihat dair kemampuan berpikir kritis siswa pada kelas yang diajarkan dengan blended learning yang memiliki nilai rata-rata posttest lebih tinggi dibandingkan dengan siswa yang diajarkan dengan metode konvensional.

Analisis data penelitian diuji dengan menggunakan uji beda. Sebelum uji beda dilakukan, dilakukannya uji prasyarat yang terdiri atas uji normalitas dan uji homogenitas. Hasil analisis inferensial data penelitian pada nilai posttest kemampuan berpikir kritis siswa pada materi suhu dan kalor dapat dilihat pada tabel 2 .

Tabel 2. Hasil Analisis Inferensial Data Kemampuan Berpikir Kritis

\begin{tabular}{lll}
\hline Parameter & Kelas Eksperimen & Kelas Kontrol \\
\hline Nilai uji normalitas & 0,810 & 0,576 \\
\hline Signifikansi uji normalitas & 0,528 & 0,895 \\
\hline Signifikansi uji homogenitas & 0,106 & \\
\hline Nilai Uji Beda & 32,700 & \\
\hline Signifikansi Uji Beda & 0,000 & \\
\hline
\end{tabular}

Tabel 2 menunjukkan hasil analisis data posttest kemampuan berpikir kritis siswa pada kelas eksperimen dan kelas kontrol adalah terdistribusi normal. Selanjutnya, hasil analisis uji homogenitas pada kelas eksperimen dan kelas kontrol juga menunjukkan bahwa data penelitian ini adalah homogen. Hal tersebut ditunjukkan dengan hasil nilai signifikansi uji normalitas dan uji homogenitas pada kelas eksperimen dan kelas kontrol lebih besar daripada 0,05 .

Selain itu, tabel 2 juga menunjukkan hasil analisis uji beda pada data posttest pada kedua kelas penelitian. Hasil uji beda tersebut menunjukkan bahwa terdapat perbedaan secara signifikan dari kemampuan berpikir kritis siswa pada siswa yang diajarkan dengan menggunakan teknik blended learning dibandingkan dengan siswa yang hanya dibelajarkan dengan metode konvensional. Hal tersebut ditunjukkan dengan nilai signifikansi uji beda pada kedua kelas $(0,000)$ yang lebih kecil dibandingkan 0,05 . 
Pembelajaran dengan menggabungkan pembelajaran tatap muka dan pembelajaran daring dapat memengaruhi kemampuan berpikir kritis siswa. Siswa yang dibelajarkan dengan menggunakan teknik blended learning mendapatkan informasi lebih banyak dibandingkan dengan siswa yang hanya dibelajarkan dengan menggunakan model konvensional. Siswa yang belajar dengan teknik blended learning mendapatkan informasi tambahan berupa materi pendalaman, video pembelajaran, dan gambar yang diberikan guru melalui Schoology. Siswa memperoleh materi pendalaman tersebut setelah pembelajaran tatap muka berakhir, sehingga siswa dapat belajar secara mandiri dimanapun dan kapanpun. Hal ini berbeda siswa kelas kontrol yang tidak menggunakan teknik blended learning, siswa tidak menerima materi pendalaman yang diberikan oleh guru. Siswa hanya menerima tugas pekerjaan rumah dan dikumpulkan pada pertemuan selanjutnya.

Berdasarkan hasil analisis dapat diketahui bahwa teknik blended learning dapat memengaruhi kemampuan berpikir kritis siswa. Hasil penelitian ini didukung dengan penelitian yang telah dilakukan sebelumnya bahwa blended learning dapat memengaruhi kemampuan berpikir kritis fisika siswa (Ardianti et al., 2019; Ningsih et al., 2018; Zarei \& Abdi, 2016). Selain itu, pembelajaran yang menggunakan teknik blended learning dapat meningkatkan kemampuan berpikir kritis siswa dibandingkan dengan siswa yang hanya belajar dengan menggunakan metode konvensional. Hal tersebut terlihat dari hasil nilai rata-rata posttest pada kedua kelas penelitian, kelas eksperimen dan kelas kontrol. Akan tetapi, hasil rata-rata kedua kelas tersebut masih belum maksimal (100\%). Hal tersebut dikarenakan siswa tidak terbiasa mendalami suatu materi yang diberikan oleh guru, tetapi siswa hanya terbiasa menerima informasi. Penelitian sebelumnya memaparkan bahwa faktor yang menyebabkan kurang maksimalnya kemampuan berpikir kritis siswa ialah siswa masih kesulitan menghubungkan antara permasalahan dengan solusi penyelesaian yang telah diperolehnya dan kesulitan dalam mengaitkan persamaan pada permasalahan yang diberikan (Arini \& Juliadi, 2018).

\section{SIMPULAN}

Berdasarkan pada paparan tersebut, maka dapat disimpulkan bahwa blended learning dapat memengaruhi kemampuan berpikir kritis secara signifikan. Selain itu, kemampuan berpikir kritis pada siswa yang belajar dengan menggunakan teknik blended learning lebih tinggi daripada kelas yang dibelajarkan dengan model pembelajaran konvensional. Hal tersebut terlihat dengan perolehan nilai rata-rata posttest siswa kelas eksperimen lebih tinggi daripada kelas kontrol.

Penggunaan Learning Management System berbantuan Schoology tidak dapat mengetahui apakah seluruh siswa telah mengunduh materi pendalaman yang telah diberikan guru pada pembelajaran daring sehingga disarankan dapat menggunakan Learning Management System selain Schoology. Selain itu, sampel yang digunakan dalam penelitian pada kedua kelas masih sedikit sehingga kesimpulan yang ditarik dalam penelitian yang telah dilakukan kurang maksimal. Oleh karena itu, disarankan untuk dapat digunakannya sampel penelitian yang lebih banyak sehingga menghasilkan kesimpulan yang lebih teliti.

\section{DAFTAR RUJUKAN}

Akyuz, H. I., \& Samsa, S. (2009). The Effects of Blended Learning Environment on the Critical Thinking Skills of Education. Procedia Social and Behavioral Sciences 1, 1744-1748.

Alonso, F., Lopez, G., Manrique, D., \& Vines, J. M. (2005). An Instructional Model for Web-Based E-Learning Education with a Blended Learning Process Approach. British Journal of Education Technology 3, 217-235.

Anggraini, A. D., Wonorahardjo, S., \& Utomo, Y. (2016). Efektivitas Pembelajaran Blended Learning Berbasis Community on Inquiry (CoI) ditinjau dari Belajar Kognitif Mahasiswa pada Materi Kromatografi. Prosiding Seminar Nasional II 10381046.

Ardianti, S., Sulisworo, D., \& Pramudya, Y. (2019). Efektivitas Blended Learning Berbasis Pendekatan STEM Education Berbantuan Shoology untuk Meningkatkan Critial Thinking Skill pada Materi Fluida Dinamik. Prosiding Seminar Nasional Pendidikan Kaluni 2, 240-246.

Arini, W., \& Juliadi, F. (2018). Analisis Kemampuan Berpikir Kritis pada Mata Pelajaran Fisika untuk Pokok Bahasan Vektor Siswa Kelas X SMA Negeri 4 Lubuklinggau, Sumatera Selatan. Berkala Fisika Indonesia 10, 1-11.

Budiarti, I. S., Suparmi., Sarwanto., \& Harjana. (2017). Students' Conceptual Understanding Consistency of Heat and Temperature. Journal of Physics: Conference Series 795, 1-5.

Ceylan, V. K., \& Kesici, A. E. (2017). Effect of Blended Learning to Academic Achievement. Journal of Human Sciences 14, 309-320.

Collins, B., Bruijstens, H., \& Veen, J .K. van der. (2003). Course Re-design for Blended Learning: Modern Optics from Technical Professional. International Journal of Continuing Engineering Education and Life-Long Learning, 13(1-2), 2238. DOI: 10.1504/IJCEELL.2003.002151.

Creswell, J. (2015). Riset Pendidikan: Perencanaan, Pelaksanaan, dan Evaluasi Riset Kualitatif dan Kuantitatif. Yogyakarta: Pustaka Pelajar.

Demirci, N. (2007). A Study about Students' Misconceptions in Force and Motion Concept by Incorporating a Web-Assisted Program. The Turkish Online Journal of Educational Technology 4, 40-48.

Dwi, I. M., Arif, H., \& Sentot, K. (2013). Pengaruh Strategi Problem Based Learning Berbasis ICT terhadap Pemahaman Konsep dan Kemampuan Pemecahan Masalah Fisika. Jurnal Pendidikan Fisika Indonesia 9, 8-17. 
Fatmawati, H., Mardiyana., \& Triyanto. (2014). Analisis Berpikir Kritis Siswa dalam Pemecahan Masalah Matematika Berdasarkan Polya pada Pokok Bahasan Persamaan Kuadrat (Penelitian pada Siswa Kelas X SMK Muhammadiyah 1 Sragen Tahun Pelajaran 2013/2014). Jurnal Elekttronik Pembelajaran Matematika, 2, 899-910.

Fitriani, H., \& Ikhsan, M. (2017). Implementasi Perangkat Pembelajaran Blended Community of Inquiry untuk Melatihkan Kemampuan Berpikir Kritis Mahasiswa Calon Guru Biologi. Prosiding Seminar Nasional Pendidik dan Pengembang Pendidikan Indonesia 187-198.

Hong, J. C., Chen, M. Y., Wong, A., Hsu, T. F., \& Peng, C. C. (2012). Developing Physics Concepts Through Hand-On Problem Solving: A Perspective on a Technological Project Design. International Journal of Technology and Design Education 22, 473-487.

Huber, C. R., \& Kuncel, N. R. (2015). Does College Teach Critical Thinking? A Meta-Analysis. Review of Educational Research 86, 431-468.

Jou, M., Lin, Y. T., \& Wu, D. W. (2016). Effect of a Blended Learning Environment on Student Critical Thinking and Knowledge Transformation. Journal Interactive Learning Environments, 24(6), 1131-1147. https://doi.org/10.1080/10494820.2014.961485

Kartal, T., Ozturk, N., \& Yalvac, H. G. (2015). Misconceptions of Science Teacher Candidates about Heat and Temperature. Procedia Social and Behavioral Sciences 15, 2758-2763. https://doi.org/10.1016/j.sbspro.2011.04.184

Kayler, M., \& Weller, K. (2007). Pedagogy, Self-Assessment, and Online Discussion Groups. Educational Technology and Society 10(1), 136-147.

Kiviniemi, M. T. (2014). Effects of a Blended Learning Approach in Student Outcomes in Graduate-Level Public Health Course. Medical Education, 14, 1-7. doi: 10.1186/1472-6920-14-47.

Korkmaz, O., \& Karakus, U. (2009). The Impact of Blended Learning Model on Student Attitudes Toward Geograpy Course and Their Critical Thinking Dispositions and Levels. The Turkish Online Journal of Educational Technology 8, 51-63.

Kurniawan, D. T. (2014). Model Pembelajaran Berbasis masalah Berbantuan Website Interaktif pada Konsep Fluida Statis untuk Meningkatkan Penguasaan Konsep dan Keterampilan Proses Sains Siswa Kelas XI. Jurnal Pengajaran MIPA, 19, 206-213.

Mabruroh, F., \& Suhandi, A. (2017). Construction of Critical Thinking Skills Test Instrument Related the Concept on Sound Wave. Journal of Physics: Conference Series, 812, 1-6.

Ningsih, W. S. A., Suana, W., \& Maharta, N. (2018). Pengaruh Penerapan Blended Learning Berbasis Schoology terhadap Kemampuan Berpikir Kritis Siswa. Jurnal Fisika dan Pendidikan Fisika 3, 85-93.

Sari, A. R. (2013). Strategi Blended Learning untuk Peningkatan Kemandirian Belajar dan Kemampuan Critical Thinking Mahasiswa di Era Digital. Jurnal Pendidikan Akuntansi Indonesia 11, 32-43.

Sudiarta, I. G. P. S., \& Sadra, I. W. (2016). Pengaruh Model Blended Learning Berbantuan Video Animasi terhadap Kemampuan Pemecahan Masalah dan Pemahaman Konsep Siswa. Jurnal Pendidikan dan Pengajaran 49, 48-58.

Warschauer, M. (2004). The Rhetoric and Reality of Aid: Promoting Educational Technology in Egypt. Globalisation Societies, and Education 2(3), 377-390. https://doi.org/10.1080/1476772042000252498.

Wong, L., Tatnall, A., \& Burgess, S. (2014). A Framework for Investigating Blended Learning Effectiveness. Emerald, 56(2-3), 233-251. https://doi.org/10.1108/ET-04-2013-0049.

Yapici, I. U., \& Akbayin, H. (2012). The Effect of Blended Learning Model in High School Students' Biology Achievement and on Their Attitudes Towards the Internet. The Turkish Online Journal of Educational Technology 11, $228-237$.

Zarei, A. A., \& Abdi, V. (2016). Blended Learning, Computer Based, and Conventional Reading Instruction Affecting Efl Learners' Self-Regulation and Critical Thinking. International Journal of Humanities and Cultural Studies 3, $2171-2187$. 